\title{
KOMUNIKASI BIROKRASI LABKESDA KABUPATEN SOLOK DALAM PENGAWASAN DEPOT AIR MINUM ISI ULANG
}

\author{
EInita $^{1}$, Ernita Arif ${ }^{2}$, Asrinaldi $^{3}$ \\ Universitas Andalas Padang \\ Email: elnitaeel@gmail.com ${ }^{1}$, argentina@yahoo.co.id ${ }^{2}$, \\ asrinaldi4@yahoo.com ${ }^{3}$
}

\begin{abstract}
Abstrak
This study aims to see the implementation of bureaucratic communication at the Labkesda Solok Regency in monitoring the quality of refill drinking water. This type of research is a qualitative approach with descriptive methods using informants as well as observation techniques, interviews, and documentation studies. The analytical tools used are induction analysis, deduction analysis, classification, and verification. Labkesda guides persuasive bureaucratic communication to drinking water depot owners. The communication that is built fulfills a regulatory function, namely ensuring the implementation of applicable regulations. Continuous communication between the government and drinking water depot owners is the main key in maintaining and increasing the compliance of drinking water depot owners. Labkesda carries out comprehensive bureaucratic communication by running formal communication channels with relevant stakeholders so that there is an increase in the compliance of drinking water depot owners in checking the quality of the drinking water they sell.
\end{abstract}

\section{Keywords: Bureaucratic communication, LABKESDA Solok Regency.}

\begin{abstract}
Abstrak
Penelitian ini bertujuan untuk melihat pelaksanaan komunikasi birokrasi Labkesda Kabupaten Solok dalam pengawasan kualitas air minum isi ulang. Jenis penelitian ini adalah pendekatan kualitatif dengan metode deskriptif dengan menggunakan informan serta melakukan teknik observasi, wawancara dan studi dokumentasi. Alat analisis yang digunakan yakni analisis induksi, analisis deduksi, klasifikasi dan verifikasi. Labkesda melakukan pembinaan melalui komunikasi birokrasi secara persuasif kepada pemilik depot air minum. Komunikasi yang dibangun memenuhi fungsi regulatif yakni menjamin pelaksanaan ketentuan berlaku. Komunikasi yang berkesinambungan antara pemerintah dan pemilik depot air minum menjadi kunci utama dalam menjaga dan meningkatkan kepatuhan pemilik depot air minum. Labkesda melakukan komunikasi birokrasi secara menyeluruh dengan menjalankan saluran komunikasi formal dengan pemangku kebijakan yang terkait sehingga terjadi peningkatan kepatuhan pemilik depot air minum dalam memeriksa kualitas air minum yang mereka perjualbelikan.
\end{abstract}

Kata Kunci : Komunikasi birokrasi, LABKESDA Kabupaten Solok

\footnotetext{
${ }^{1}$ Mahasiswa Magister Ilmu Komunikasi Universitas Andalas, Universitas Andalas Padang

2 Dosen Fakultas Ilmu Sosial Ilmu Politik Universitas Andalas Padang

3 Dosen Fakultas Ilmu Sosial Ilmu Politik Universitas Andalas Padang
} 


\section{A. Pendahuluan}

Komunikasi merupakan sebuah interaksi antara dua atau lebih manusia yang melibatkan proses pengiriman serta penerimaan pesan dari komunikator atau sumber informasi kepada komunikasi atau target pesan. Dengan demikian dapat kita ketahui bahwa komunikasi terdiri dari beberapa unsur yang mempengaruhinya. Unsur tersebut antara lain komunikator, pesan, media komunikasi, komunikan dan feedback. Kelima unsur tersebut merupakan unsur utama dalam komunikasi yang menandakan adanya proses komunikasi yang berlangsung. Jika hanya komunikator dan pesan saja tanpa adanya feedback dari komunikan, komunikasi hannya berjalan satu arah. Organisasi merupakan suatu macam bentuk perkumpulan antara manusia yang saling berinteraksi atau saling berbagi dalam menjalankan kehidupannya sebagai mahluk sosial.Sebuah organisasi yang dianggap baik adalah organisasi yang dapat memanajemen suatu organisasi dengan baik sehingga menghasilkan kinerja yang efektif dan efisien, baik itu kinerja pegawai maupun kinerja organisasi.

Komunikasi ini memiliki tujuan tertentu, baik untuk mentransfer ide, mengedukasi, atau untuk mengubah sesuatu. Agar tujuan komunikasi tercapai maka seluruh proses komunikasi harus berjalan dengan baik. Agar proses komunikasi berjalan dengan baik, maka setiap unsur dalam komunikasi harus diperhatikan sedemikian rupa, sehingga dapat menghasilkan feedback positif dari komunikan.

Secara umum, model birokrasi sering dianologikan sebagai kultur feodalisme dalam pemerintahan di Indonesia. Didalamnya mengandung hak komunikasi yang lebih ditekankan kepada hak komunikasi para pemiliki kekuasaan dalam strukturstruktur pemerintahan.Padahal, sebenarnya birokrasi adalah model ideal untuk mencapai tujuan organisasi yang juga mengunggulkan peran serta berbagai pihak dalam strktur untuk bekerja sesuai dengan kapasitas dan tanggungjawabnya. Birokrasi juga sering dikaitkan dengan system pengawasan dan wewenangnya sangat ketinggalan jaman.Ini dapat terjadi karena pola penyimpangan berjalan sesuai dengan perkembangan ilmu dan teknologi, dilain pihak birokrasi menetapkan prosedur pengawasan selalu membutuhkan waktu yang sangat panjang. 
Selain itu menurut Bennis dalam Myers dan Myers (1988:34), birokrasi tidak mempunyai proses peradilan, dalam arti birokrasi hanya mampu memberikan sanksi administratif terhadap penyimpangan dan penyalahgunaan kekuasaan, tidak memiliki alat-alat yang cukup untuk menyelesaikan perbedaan-perbedaan dan konflik-konflik antara berbagai tingkatan (rank).

Upaya meningkatkan pelayanan kepada publik dan menciptakan kekuatan masyarakat madani, diperlukan kepemimpinan birokrasi yang mampu mampu berinteraksi dan berkomunikasi dengan seluruh lapisan masyarakat. Kepemimpinan dalam perspektif komunikasi adalah suatu kegiatan komunikasi untuk mempengaruhi orang-orang supaya dapat bekerjasama dalam mencapai tujuan yang diinginkan. Pola penyelesaian yang merujuk pada pedoman sentral yang seragam sering tidak mampu untuk menyelesaikan konflik dengan baik. Kurang berhasilnya komunikasi dalam organisasi disebabkan antara lain karena karakteristik sifat dinamis yang dimiliki oleh organisasi, dimana organisasi merupakan sebuah system terbuka yang terus menerus mengalami perubahan karena selalu menghadapi tantangan baru dari lingkungan sekitar dan perlu menyesuaikan diri dengan keadaan lingkungan yang selalu berubah tersebut (Muhammad, 2011).

UPTD LABKESDA berdiri pada tahun 2011 berfungsi untuk pelayanan pembangunan kesehatan sebagai Upaya Kesehatan Masyarakat (UKM) dan Upaya Kesehatan Perorangan (UKP) berupa pencegahan dan pemberantasan penyakit, penyediaan dan pengelolaan air bersih dan penyehatan lingkungan pemukiman serta kegiatan lain yang ada di wilayah Kabupaten Solok. Pengawasan Kualitas Air melalui pemeriksaan kualitas air berkala merupakan bentuk pelayanan kepada masyarakat dan mencegah penggunaan air yang dapat membahayakan kesehatan masyarakat. Depot air minum hakikatnya hadir ditengah masyarakat untuk memudahkan masyarakat dalam memenuhi kebutuhan air minum, apalagi melihatkondisi masyarakat urban yang sebagian besar memanfaatkan teknologi untuk mengefektifkan waktu dalam pemenuhan kebutuhan sehari-hari.

Di Kabupaten Solok, usaha depot air minum isi ulang terbilang meluas hampir disetiap kecamatan memiliki usaha depot air minum isi ulang. Dan kualitas air serta lokasi dan pelayanannya bervariasi. Sayangnya masyarakat 
sebagian besar belum bisa mebedakan air minum yang kualitasnya baik dan yang buruk. Berdasarkan temuan penulis bersumber dari informasi terpercaya, penulis menemukan bahwa di Kabupaten Solok lebih dari 130 depot air minum isi ulang yang ada, hanya 15 depot diantaranya rutin memeriksa kualitas air minum yang mereka perjualbelikan secara berkala. Temuan yang berdasarkan uraian fenomena diatas merupakan hal yang sangat krusial, karena efeknya bagi kesehatan berjangka panjang dan menyangkut masyarakat umum.

Pengawasan menjadi pintu utama bagi pemerintah dalam melindungi konsumen depot air minum.Namun pengawasan yang telah dilakukan belum maksimal, pemilik depot air minum isi ulang tetap tidak mematuhi ketentuan untuk memeriksa kualitas air minum secara berkala.Komunikasi merupakan hal yang sangat penting dalam pengawasan oleh Labkesda.Seringkali perbedaan prespektif menjadi hambatan tersendiri dalam berkomunikasi.Pemilik depot air minum sebagai penerima pesan sering mengabaikan pesan yang diberikan oleh Labkesda. Hambatan komunikasi terjadi karena kepentingan berbeda dan pemaknaan pesan terabaikan. Petugas Labkesda dalam menjalankan fungsi pengawasan selalu membawa leatflet yang berisikan informasi cara pemeriksaan dan pentingnya dilakukan pemeriksaan laboratorium.

Saluran komunikasi secara langsung yang dilaksanakan secara komunikasi interpersonal belum maksimal mengugah hati pemilik depot air minum. Komunikasi interpersonal yang dilakukan oleh petugas Labkesda diharapkan mampu menyampaikan informasi,berbagi pengalaman, simpati sehingga akan menghasilkan kerjasama yang baik. Komunikasi yang dibangun dilakukan dengan sikap toleransi, kesempatan-kesempatan seimbang,saling menghargai sehingga menimbulkan suasana hangat dan keakraban. Hambatan komunikasi aspek psikologis antara Labkesda dan pemilik depot air minum membuat tujuan pengawasan tidak tercapai.Tujuan utama kegiatan komunikasi adalah untuk memastikan komunikan memahami makna dari pesan yang diterima (to secure understanding), terus memelihara dan membina penerimaan tersebut (to establish acceptance), dan memotivasi komunikan untuk melakukan suatu kegiatan (to motive action). 
Untuk itu penulis melakukan penelitian tentang persoalan komunikasi birokrasi UPTD LABKESDA dalam pengawasan Depot Air Minum Isi Ulang. Penelitian ini bertujuan untuk melihat dimana terjadi hambatan komunikasi birokrasi dalam pengawasan depot air minum dan usaha apa yang telah ditempuh untuk pengawasan depot air minum isi ulang ini berjalan lebih efektif.

\section{A. Landasan Teori}

Secara etimologis istilah komunikasi berasal dari bahasa latin communication dan perkataan ini bersumber pada kata communis. Perkataan communis tersebut dalam pembahasan ini sama sekali tidak ada kaitannya dengan partai komunis yang sering dijumpai dalam kegiatan politik. Arti communis disini adalah sama dalam arti kata sama makna yaitu sama makna mengenai suatu hal. Kesamaan makna dalam proses komunikasi merupakan faktor penting karena dengan adanya kesamaan makna antara komunikan dan komunikator maka komunikasi dapat berlangsung dan saling memahami. Begitu juga dengan Birokrasi sebagai masyarakat modern,mengacupada suatu kondisi dimana masyarakat tunduk kepada aturan-aturan yang diselenggarakan oleh birokrasi. Untuk itu, tidak dibedakan antara birokrasi perubahan swasta besar ataupun birokrasi negara.

Selama masyarakat tunduk kepada aturan-aturan yang ada didua tipe birokrasi tersebut, maka dikatakan bahwa masyarakat tersebut dikatakan modern. Ruang lingkup birokrasi dapat diketahui berdasarkan perbedaan tugas pokokdan misi yang mendasar organisasi birokrasi adalah:

1. Birokrasi pemerintahan umum, yaitu rangkaian organisasi pemerintahan yang menjalankan tugas-tugas pemerintahan umum dari tingkat pusat sampai daerah (Propinsi, Kabupaten, Kecamatan dan Desa/ Kelurahan). Dalam proses komunikasi dapat dipahami bahwa keberadaan penerima adalah akibat adanya sumber.

2. Birokrasi fungsional, yaitu organisasi pemerintahan yang menjalankan salah satu bidang atau sektor yang khusus guna mencapai tujuan umum pemerintahan. Hal yang paling penting diperhatikan dalam birokrasi ini adalah pesan yang disampaikan dapat dimengerti dan dipahami oleh komunikan. Mengingat hal ini maka yang perlu diperhatikan adalah pemilihan bentuk 
pesan dan cara penyajian pesan termasuk juga penentuan saluran/media yang harus dilakukan oleh komunikator sebagai penyampai pesan.

Birokrasi pelayanan (service-Bureaucracy), yaitu unit organisasi yang ada hakekatnya melaksanakan pelayanan langsung dengan masyarakat. Termasuk dalam konsep ini apa yang disebut oleh Michael Lipsky sebagai "Street-level Bureaucracy”, yaitu mereka yang menjalankan tugas dan berhubungan langsung dengan warga masyarakat. Praktik komunikasi efektif dalam organisasi diterapkan dalam kegiatan organisasi antar unit dalam organisasi merupakan bagian-bagian yang saling bergantung satu sama lain dalam pelaksanaan kegiatan organisasi. Dalam perspektif komunikasi, menjalankan roda organisasi pemerintah harus mengunggulkan perilaku komunikasi integratif, demi untuk menghasilkan kesepatan bersama dalam menyikapi kebijakan publik. Dan koordinasi memerlukan komunikasi ,terutama dari pihak manajemen organisasi.Dalam pelaksanaanya,untuk mencapai hasil komunikasi yang efektif tersebut, seringkali organiasi menghadapi hambatan-hambatan dalam proses omunikasi lapangan.

Dari uraian diatas dapat disimpulkan bahwa komunikasi pemerintahan pada hakekatnya merupakan proses penyebaran dan pertukaran informasi di dalam dan dengan luar organisasi. Melalui komunikasi pemerintahan,maka pihak eksekutif (pemerintah) bertukar dan membagi informasi dengan yang lain yaitu dengan legislatif, dengan staf, pelaku bisnis dan masyarakat. Melalui komunikasi, pihak eksekutif atau administrator bermaksud mempengaruhi sikap, pemahaman serta perubahan prilaku birokrasi dan masyarakat. Dengan demikian,tiap orang yang terlibat dalam penyelenggaraan pemerintahan demokratis merupakan bagian dari proses komunikasi birokrasi baik sebagai pemberi pesan di satu waktu dan di waktu lain sebagai penerima pesan.Saling keterkaitan antara semua pihak membuat permasalahan semakin kompleks dan membutuhkan kemampuan komunikasi yang baik dan efektif.

Strategi komunikasi pada hakekatnya adalah perencanaan (planning) dan manajemen untuk mencapai satu tujuan. Untuk mencapai tujuan tersebut, strategi tidak berfungsi sebagai peta jalan yang hanya menunjukan arah saja, melainkan harus menunjukan bagaimana taktik operasionalnya. Strategi komunikasi merupakan paduan dari perencanaan komunikasi dan manajamen komunikasi 
untuk mencapai satu tujuan (Effendi, 2003). Menurut Dye (1978) dalam Subarsono (2012) Evaluasi kebijakan dalam perspektif alur proses/ siklus kebijakan publik yang telah dibuat dan telah dilaksanakan lalu dievaluasi.

Hasil penelitian terdahulu yang pertama berkaitan dengan pengawasan depot air minum isi ulang yaitu oleh Pradana, A.Y.Bowo Joko Marsono (Jurnal Teknik Promits), dengan judul Uji Kualitas Air Minum Isi Ulang di Kecamatan Sukodono, Sidoarjo ditinjau dari perilaku dan pemeliharaan alat tahun 2013. Tujuan penelitian ini melihat kualitas air minum yang diperjualbelikan oleh depot air minum di Kecamatan Sukodono Sidoarjo, kelebihan dari penelitian ini yaitu peneliti melakukan penelitian terhadap alat yang dipakai di depot air minum. Uji kelayakan pemakaian lampu Ultra Violet dan filter carbon menunjukkan dari 8 depot hanya 5 depot yang pemeriksaan teknis alat yang dinilai cukup. Cemaran bakteri menunjukkan pengusaha depot air minum tidak terlalu peduli akan kualitas air isi ulang yang mereka perjualbelikan, dan kelemahan dari penelitian ini yaitu hanya 8 depot yang diperiksa dimana jumlah itu tidak memadai sebagai sampel penelitian dimana dikecamatan itu jumlah depot air minum lebih dari 40 .

Hasil penelitian terdahulu yang kedua berkaitan dengan pengawasan depot air minum isi ulang yaitu oleh diatma, R, Danang Endarto, Setya Nugraha (Jurnal), dengan judul Studi Persebaran Depot Air Minum Isi Ulang dan Kualitas Air Minum Isi Ulang secara Mikrobiologis di Kecamatan Jebres Kota Surakarta Tahun 2014. Tujuan penelitian ini bertujuan untuk mengetahui sebaran geografis depot air minum di Kecamatn Jebres, kelebihan dari penelitian ini yaitu penelitian ini dilakukan oleh mahasiswa geografi dengan tujuan melihat pola sebaran depot air minum. Penelitian ini menyimpulkan bahwa semakin ramai penduduk didekat depot air minum maka semakin cepat putaran air yang diperjualbelikan sehingga waktu tumbuh bakteriologis sedikit dan membuat cemaran bakteri dalam air berkurang. Kelemahan dari penelitian ini yaitu penelitian ini tidak menjelaskan secra utuh hubungan depot air yang melayani pelanggan dengan system antar dengan kontaminasi bakteri. Komunikasi dengan dinas kesehatan juga tidak tergambar.

Sebuah penelitian memerlukan dukungan dari hasil penelitian yang sebelumnya yang berkaitan dengan penelitian tersebut. Hasil dari penelitian 
terdahulupun dapat berperan sebagai bahan perbandingan dan acuan dalam pelaksanaan penelitian yang dilaksanakan. Berikut adalah beberapa penelitian terdahulu yang dapat menunjang penelitian ini dengan menunjukkan beberapa penelitian yang relevan dengan penelitian peneliti.

Pengawasan eksternal dilakukan oleh dinas kesehatan Kabupaten Solok bersama perangkat daerah bertujuan untuk pembinaan dan pengawasan depot air minum jika ada :

1. Keluhan masyarakat yang diberikan pada situs lapor.go.id kabupaten solok dari masyarakat.

2. Kejadian luar biasa (KLB) yang menyangkut konsumsi air minum isi ulang.

Pengawasan Manullang (2006) menyatakan bahwa proses pengawasan dimanapun juga atau pengawasan yang berobjekkan apapun terdiri dari langkah sebagai berikut :

1. Menetapkan alat pengukur (standar).

2. Mengadakan penilaian.

3. Mengadakan tindakan perbaikan.

Pada prinsipnya komunikasi yang efektif harus menciptakan kesamaan makna antara pengirim dan penerima pesan.Karena ada kesepakatan ataupun kesepahaman pihak yang melayani dan dilayani, maka harapan masyarakat untuk memperoleh pelayanan publik yang lebih baik bisa diwujudkan.Kepemimpinan dalam system demokrasi diperlukan kemampuan berkomunikasi, persuasi, kesabaran mengajak dan meyakinkan,ketahanan menjalani perbedaan, mendengarkan kritik tetapi sebaliknya setiap kali harus mau dan mampu menemukan pengertian,saling pengertian, kesepakatan dan kesepahaman (Oetomo, 2009:88).

Manajemen pengawasan adalah upaya penerapan standar pelaksanaan, merancang sitem informasi umpan balik, membandingkan kegiatan nyata dengan standar yang ada menentukan dan mengukur penyimpangan-penyimpangan serta mengambil tindakan koreksi yang diperlukan untuk menjamin bahwa usaha atau kegiatan telah dilaksanakan secara baik dalam mencapai tujuan. Pengawasan harus dilakukan dengan intensif agar tidak berdampak dan berisiko pada kesehatan masyarakat yang akan dirasakan dalam jangka panjang apabila ada 
pelaku usaha yang hanya bertujuan mencari keuntungan tanpa memperhatikan standar yang telah ditetapkan, pelaku usaha mempunyai kewajiban untuk berhatihati dalam memasyarakatkan produk, baik barang maupun jasa.

Parameter atau tolak ukur kebijakan harus dibuat agar evaluasi pelaksanaan kebijakan dapat dilaksanakan. Esensinya, unsur-unsur yang menonjol dalam pengawasan adalah kemampuan berkomunikasi untuk mempengaruhi seseorang atau kelompok dengan cara yang tidak memaksakan kehendak,tetapi kegiatan mempengaruhi sebagai satu hal yang tidak mudah dilakukan. Kendala-kendala yang ditemui dalam pengawasan memerlukan unsur pemaksaan dalam memastikan keberhasilan pengawasan.

\section{Gambar 1 Kerangka Berfikir}

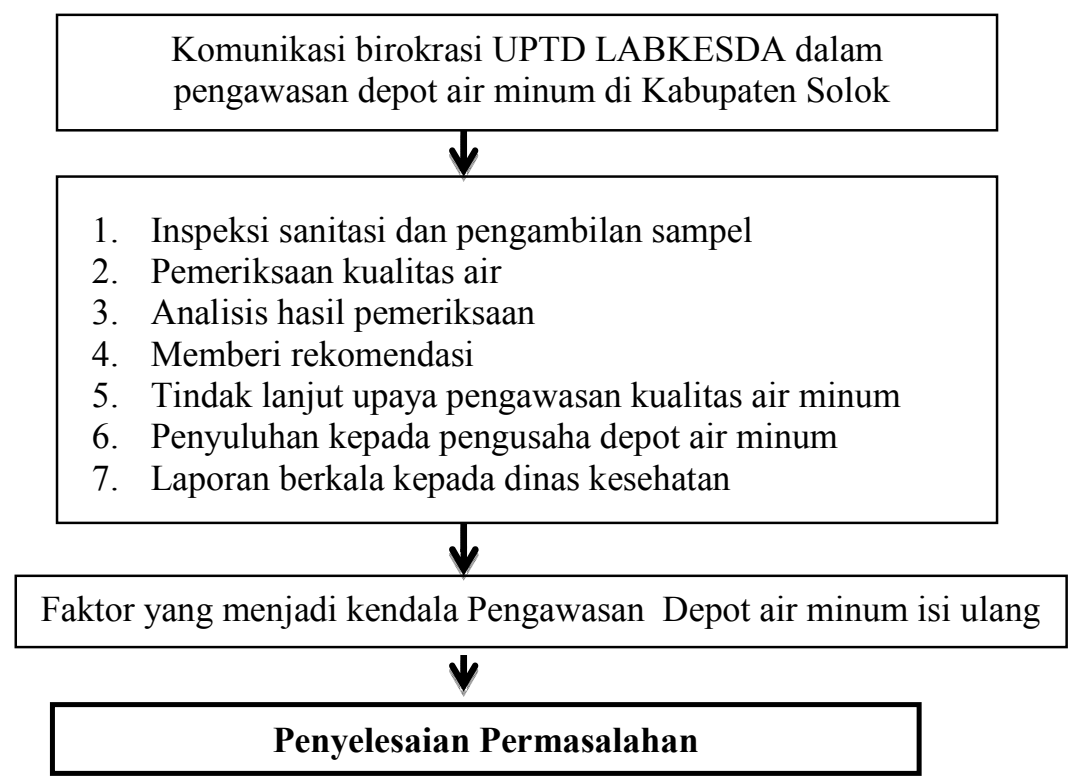

Sumber : Olahan Peneliti berdasarkan pendapat Stephen P. Robbins (2010:161)

\section{B. Metode Penelitian}

Penelitian ini telah dilaksanakan di Kabupaten Solok tepatnya pada kantor UPTD LABKESDA Sukarami-Solok. Alasan memilih lokasi ini dikarenakan peneliti menemukan masih ada masalah-masalah yang belum bisa diselesaikan. Jenis penelitian ini adalah pendekatan kualitatif dengan metode deskriptif. Peneliti berusaha untuk mengungkapkan fakta sesuai dengan kenyataan yang ada tanpa melakukan intervensi terhadap kondisi yang terjadi. Pada penelitian kualitatif dengan metode deskriptif adalah suatu jenis penelitian yang bertujuan untuk 
membuat deskriptif (gambaran) dan hubungan antara fenomena yang diselidiki. Penelitian deskriptif tidak memberikan perlakuan, manipulasi atau pengubahan pada variabel-variabel bebas, tetapi menggambarkan suatu kondisi apa adanya.

Subjek/informan dalam penelitian ini adalah seluruh pegawai yang bekerja di UPTD LABKESDA Kabupaten Solok. Menurut (Sugiyono, 2003) subjek penelitian adalah pihak yang mengetahui atau memberikan informasi maupun kelengkapan mengenai objek penelitian. Dalam penelitian ini peneliti menggunakan informan penelitian melalui key informan. Dalam penelitian ini yang menjadi informan penelitian adalah:

1. Informan kunci (key informan) adalah orang yang mengetahui permasalahan secara mendalam. Adapun yang menjadi informan kunci dalam penelitian ini adalah kepala UPTD LABKESDA, Kepala Tata Usaha LABKESDA, staf pemeriksa kimia fisika sampel air, kasi kesehatan lingkungan dan olahraga Dinas Kesehatan serta pengusaha depot air minum.

2. Informan pelengkap adalah orang yang dianggap mengetahui mengenai permasalahan ini walaupun tidak terlibat secara langsung dalam permasalahan ini. Adapun yang menjadi informan pelengkap dalam penelitian ini adalah Sanitarian Puskesmas dan Masyarakat yang membeli air minum isi ulang.

\section{Teknik Pengumpulan Data}

1. Observasi dilakukan dengan cara mengamati langsung kepada objek penelitian. Pengamatan ini dilakukan baik secara terbuka atau terselubung.Pengamatan dilakukan juga dengan berupaya mendekatkan diri dengan para aktor agar bisa mengetahui dan menggali informasi dengan mudah.

2. Wawancara yang dilakukan dengan berbicara langsung dengan sumber informasi dengan cara mewawancarai informan secara langsung dan tanya jawab mendalam tentang hal-hal relevan dengan penelitian, dengan maksud untuk menggali lebih jauh fenomena yang terjadi. Sedangkan pertanyaan dalam wawancara bersifat terbuka dengan mengedepankan kreatifitas dalam menggali informasi yang diinginkan. 
3. Studi dokumentasi dilakukan untuk mengumpulkan data-data administratif ataupun arsip dari kegiatan yang ditemui oleh peneliti di lapangan. Dokumen yang diteliti yaitu yang berhubungan dengan tugas informan dan lain sebagainya. Dalam hal ini peneliti mendokumentasikan setiap informasi yang didapat dari informan sebagai bukti penelitian, berupa rekaman wawancara dengan informan.

\section{Teknik Analis Data}

Analis data adalah pengolahan data dan penafsiran data.Analisis data merupakan uapaya mencari dan menata sistematis catatan hasil observasi, wawancara dan lainnya sesuai dengan jenis dan golongan yang sudah disiapkan peneliti sehingga dapat meningkatkan pemahaman peneliti tentang kasus yang diteliti dapat menyajikan hasil temuan peneliti secara mudah. Dalam analisis data digunakan beberapa macam analisis yaitu: analisis induksi, analisis deduksi, klasifikasi dan verifikasi. Analisis induksi yaitu penarikan kesimpulan yang dimulai dengan menyatakan pernyataan-pernyataan yang mempunyai ruang lingkup yang khas dan terbatas dalam menyusun argumentasi yang diakhiri dengan pernyataan-pernyataan umum. Sedangkan analisis deduksi yaitu suatu penarikan kesimpulan dari suatu pernyataan-pernyataan yang umum kedalam pernyataan khusus diakhir. Analisis data bertujuan menyempitkan dan membatasi penemuan-penemuan sehingga menjadi suatu data yang teratur, tersusun dan lebih berarti. Dari data yang berhasil dikumpulkan akan disusun, dianalisis sesuai dengan ketentuan atau jenis masing-masing yang sudah disipakan dalam menjawab adanya pertanyaan bagaimana (induksi) dan apa saja (deduksi).

\section{Hasil}

Pengawasan kualitas air minum adalah proses dalam menetapkan ukuran kinerja organisasi yakni UPTD LABKESDA dalam melakukan pengawasan terhadap kualitas air yang diperjualbelikan pengusaha depot air minum isi ulang untuk dikonsumsi masyarakat umum. Pengawasan adalah tindakan yang dapat mendukung pencapaian hasil yang diharapkan sesuai dengan ukuran yang telah ditetapkan tersebut.Pengawasan merupakan salah satu upaya yang diterapkan agar pelaksanaan pekerjaan dapat sesuai dengan tujuan yang telah ditetapkan.Menurut 
Arnold dan Feldman(1986), komunikasi organisasi (Birokrasi) adalah pertukaran informasi dari orang-orang dimana informasi itu harus mengandung kebenaran, perhatian dan menyeluruh walaupun informasi itu akan menimbulkan hambatan (retensi).

Hambatan terhadap komunikasi bisa berasal dari internal maupun eksternal. Hambatan internal adalah ketidak mampuan petugas Labkesda dalam melakukan pendekatan ersuasif dengan komunikasi interpersonal kepada pemilik depot air minum. Pendekatan humanistik petugas Labkesda kurang efektif meskipun setiap pemantauan lapangan,petugas Labkesda selalu membawa petugas sanitarian Puskesmas untuk membantu melakukan pendekatan ke pemilik depot air minum.

Salah satu teori komunikasi organisasi yang popular adalah komunikasi relasi publik dimana dalam penerapan komunikasi organisasi,komunikasi disusun secara terencana dan berkesinambungan agar tujuan organisasi terwujud.Berdasarkan hasil wawancara yang dilakukan kepada beberapa informan yaitu Kepala UPTD Labkesda, Kepala Tata Usaha Labkesda, sataf pemeriksa kimia fisika sampel air.Staf pemeriksa mikrobiologi sampel air, Kasi Kesehatan Lingkungan dan Olahraga Dinas Kesehatan serta pengusaha depot air minum. Wawancara ini dilaksanakan dari bulan April 2018 sampai Juli 2019 dimana kesimpulan penelitian, sebagai berikut:

Inspeksi sanitasi adalah pengawasan pada air minum perpipaan maupun air minum dalam kemasan dilakukan pada seluruh unit pengolahan air minum, mulai dari sumber air baku, instalasi pengolahan, serta proses pengemasan, sedangkan pengambilan sampel adalah jumlah, frekuensi dan sampel air minum harus dilaksanakan sesuai kebutuhan dengan ketentuan minimal sebagai berikut yaitu Pemeriksaan kualitas bakteriologis dan pemeriksaan kualitas kimiawi. Waktu pemeriksaan Inspeksi sanitasi dan pengambilan sampel yakni 3 bulan sekali, hal ini dilakukan untuk mengetahui apakah air tersebut layak dikonsumsi masyarakat atau tidak. Dalam pelaksanaan inspeksi sanitasi, petugas Labkesda menerapkan komunikasi interpersonal humanistik Joseph Devito. Petugas Labkesda memperhatikan aspek reability yaitu pemberian informasi serta petunjuk teknis yang tepat dan benar. Aspek Responsiveness (tanggung jawab) dilakukan dengan cara memberikan petunjuk secara cepat dan adanya perhatian serta dukungan 
moral sebagai implementasi aspek Assurance (jaminan). Dalam pengawasan inpeksi sanitasi air minum isi ulang di Kabupaten Solok yang dilakukan oleh UPTD Labkesda bersama dengan pengusaha depot air minum isi ulang, mereka tidak bisa melakukan pengendalian kegiatan dalam upaya terhadap inpeksi sanitasi air, hal ini disebabkan sebagai berikut:

1. Pengusaha depot air minum isi ulang jarang meminta sertifikasi hasil pemeriksaan kualitas air minum dari penyuplai air baku. Ini karena mereka menganggap bahwa air baku yang berada di Arosuka merupakan air minum yang berkualitas terbaik di Kabupaten Solok. Petugas Labkesda melakukan pendekatan komunikasi dengan cara menghindari perselisihan dengan pemilik depot air minum. Petugas mendengarkan semua keluhan pemilik depot air minum serta memberikan kontak telepon yang bisa dihubungi.

2. Depor air minum dilarang mengambil air baku yang berasal dari air PDAM yang ada dalam jaringan distribusi untuk rumah tangga. Faktanya ada puluhan depot air minum menggunakan air PDAM maupun air PDAM Nagari yang berasal dari program Pamsimas.Petugas Labkesda memberikan gambaran kerugian jika memakai PDAM sehingga pemilik depot air minum dapat memahami resiko yang akan mereka hadapi jika memakai air PDAM. Komunikasi interpersonal pragmatis cenderung bekerja pada penerima pesan (pengusaha) yang masih suka membandel terhadap ketentuan ini. Petugas mampu memberikan informasi dengan kepercayaan diri yang tinggi sehingga pemilik depot air minum tertarik untuk mematuhi himbauan petugas Labkesda.

3. Pemilik depot air minum tidak melaksanakan kewajiban hygienis karyawan seperti memakai masker saat mengisi gallon air, memeriksa kesehatan karyawan dari penyakit menular.Komunikasi yang dilakukan oleh petugas Labkesda adalah dengan memberikan informasi tentang keuntungan memeriksa kesehatan karyawannya dengan memahami gaya komunikasi pemilik depot air minum yang berbeda-beda.Komunikasi dengan berorientasi kepada orang lain membuat komunikasi berjalan lancar.

Pengamatan yang dilakukan tersebut haruslah sesuai atau berjalan dengan apa yang disampaikan dan diintruksikan dan sesuai dengan prinsip yang telah 
ditetapkan. Pengawasan bertujuan menunjukkan dan menemukan kelemahankelemahan dalam melaksanakan inpeksi sanitasi pada pengawasan kualitas air minum isi ulang di Kabupaten Solok dan memperbaiki kesalahan tersebut agar tidak terulang kembali. Pendekatan komunikasi interpersonal humanistik serta pragmatis dilakukan petugas Labkesda tetapi masih banyak pemilik depot air minum yang tidak memenuhi ketentuan yang berlaku. Hal ini diatas membuktikan bahwa masih banyak depot air minum isi ulang yang tidak memenuhi syarat pengawasan internal air minum.

Maka setiap masalah yang terjadi seharusnya dapat diselesaikan melalui jalur komunikasi konstruktif, karena komunikasi adalah roh birokrasi.Tanpa komunikasi, birokrasi tidak dapat berjalan dan bekerja sebagaimana mestinya. Komunikasi konstruktif merupakan suatu upaya yang sistematis untuk menerapkan kinerja standar pada perencanaan untuk merancang system umpan balik informasi, untuk membandingkan kinerja standar pada perencanaan, untuk membandingkan kinerja aktual dengan standar yang telah ditentukan untuk menetapkan apakah telah terjadi suatu penyimpangan dan mengukur signifikan penyimpangan tersebut serta untuk mengambil tindakan perbaikan yang diperlukan untuk menjamin bahwa semua sumber daya perusahaan telah digunakan seefektif dan seefisien mungkin guna mencapai tujuan organisasi. Pendekatan top down oleh kepala daerah bisa mengisi kekosongan saat perda pengawasan depot air minum belum terwujud karena sesungguhnya birokrasi memiliki wewenang mengatur masyarakat. Kewenangan merupakan otoritas atau legitimasi bagi para pelaksana dalam melaksanakan kebijakan yang ditetapkan secara politik. Dinas kesehatan dan jajarannya bisa mengundang pengusaha depot air minum dalam pembinaan dengan melibatkan pihak kepolisian dan Wali Nagari sehingga ada komitmen yang terus terjaga dalam melindungi masyarakat dari bahaya kontaminasi air minum isi ulang yang tidak memenuhi persyaratan.

\section{E. Pembahasan}

Pemeriksaan kualitas air pengawasan terhadap pemeriksaan kualitas air minum dilaksanakan di laboratorium kesehatan daerah Kabupaten Solok atau laboratorium kesehatan daerah lainnya sesuai dengan ketentuan yang sudah 
ditetapkan. Hasil wawancara diatas dihubungkan dengan teori yang digunakan dalam penelitian ini, menurut G.R Terry dalam Sarwoto (2003:55) mengatakan bahwa pengawasan adalah proses memilih apa yang akan dilaksanakan, mengevaluasi pelaksanaan dan bilamana perlu menerapkan tindakan-tindakan korektif sedemikian rupa sehingga pelaksanaan sesuai rencana. Hasil wawancara menunjukkan bahwa kualitas air minum yang diperiksa hampir semuanya sesuai persyaratan. Pemeriksaan kualitas air secara kimia dan fisika menunjukkan lebih 98\% memenuhi syarat.

\section{Analisis Hasil Pemeriksaan Kualitas Air}

Cara menganalisis hasil pemeriksaan kualitas air minum, untuk melihat kandungan bakteri yang terdapat di dalam air tersebut. Menganalisis apakah air tersebut layak dikonsumsi oleh masyarakat dilihat dari hasil uji laboratorium, yakni dengan melihat parameter yang berhubungan langsung dengan kesehatan, yakni parameter mikrobiologi dan kimia organik apakah air tersebut layak dikonsumsi masyarakat atau tidak, setelah itu baru diambil sebuah kesimpulan, jika layak maka akan diberi rekomendasi untuk diperjualbelikan kepada masyarakat.

UPTD LABKESDA memberikan informasi tentang biaya pemeriksaan secara jelas dan tanpa adanya pungutan diluar tarif yang ditetapkan dalam perda tarif yang berlaku.Lama pemeriksaan sampel air sesuai waktu yaitu paling lambat seminggu. Hasil pemeriksaan bersifat rahasia dan hanya bisa diambil oleh pemilik depot air minum atau sanitarian puskesmas tempat depot air minum berusaha. Hal diatas menunjukkan bahwa UPTD LABKESDA telah melakukan penyampaian informasi serta adanya aspek kesetaraan antara masyarakat dan birokrasi dalam berkomunikasi.

Komunikasi Labkesda dan pemilik depot air minum seyogyanya mengarah pada terciptanya hubungan kemitraan (partnership) antara keduanya. Labkesda yang mengetahui teknik pemeriksaan serta hasil pemeriksaan sampel air, namun pemilik depot air minum yang "berhak" atas kesinambungan usahanya. Karena itu Labkesda perlu mendengarkan dan merespon keluhan, kekahawatiran serta preferensi atas hasil pemeriksaan sampel air minum. Labkesda juga harus membantu pemilik depot air minum menetapkan teknik produksi air minum yang 
baik melalui pemberian informasi yang dibutuhkan oleh pemilik depot air minum. Banyak rambu-rambu komunikasi yang tidak boleh dilanggar oleh Labkesda dalam berhubungan dengan pemilik depot air minum seperti prinsip kerahasiaan, diskriminasi serta memanfaatkan pemilik depot air minum untuk kepentingan pribadi.

Fungsi ganda strategi komunikasi baik secara makro (planned multi-media strategy) maupun secara mikro (single communication medium strategy) adalah untuk menyebarluaskan informasi yang bersifat informative, persuasive dan instruktif secara sistemik kepada sasaran untuk memperoleh hasil yang optimal. Pengawasan dalam pemberian rekomendasi kualitas air bersih, saran yang menganjurkan atau menguatkan untuk menindaklanjuti dari hasil pemeriksaan kualitas air di laboratorium apakah air yang sudah di uji kualitasnya layak di konsumsi atau tidak oleh masyarakat. Rekomendasi yang diberikan demi tercapainya publik service. Rekomendasi merupakan salah satu metode komunikasi yang bersifat kursif (pemaksaan). Dengan adanya ketentuan rekomendasi maka pemilik depot air minum dipaksa untuk melaksanakan ketentuan yang berlalu. Pemberian rekomendasi baru maupun perpanjangan usaha depot air minum isi ulang yang dikeluarkan oleh Dinas Penanaman Modal PTSP serta tenaga kerja (DPMPTSP) paling lama 10 hari kerja setelah rekomendasi yang dikeluarkan oleh dinas kesehatan. Ini menunjukkan adanya keterbukaan informasi dalam komunikasi birokrasi sehingga kualitas pelayanan publik semakin baik ke depan.

\section{Tindak Lanjut upaya pengawasan kualitas air minum.}

Tindak lanjut dalam upaya penanggulangan/perbaikan mengenai pengawasan kualitas air minum merupakan usaha untuk memperbaiki permasalahan yang terjadi saat pemeriksaan kualitas air minum di laboratorium.Tindak lanjut membutuhkan kemampuan komunikasi yang baik. Labkesda sebagai sumber informasi harus mampu menyampaikan pesan secara efektif agar tindak lanjut upaya pengawasan kualitas air minum dapat tercapai. Untuk menjadi komunikator (Labkesda) yang baik, terdapat beberapa hal yang perlu dipahami, yakni perlu menyusun dengan baik isi pesan yang akan disampaikan, sehingga pesan tersebut mudah dimengerti oleh pihak penerima (Pemilik Depot Air Minum). Komunikator 
yang baik juga harus mengetahui mana media yang paling tepat untuk mengirimkan pesan kepada penerima dan harus tahu bagaimana cara mengantisipasi gangguan yang akan muncul pada proses pengiriman pesan.Selain itu,komunikator yang baik akan bertanggung jawab memberikan tanggapan terhadap umpan balik (Feedback) yang disampaikan oleh pihak penerima (receiver).Tindak lanjut itu membutuhkan kemampuan komunikasi mumpuni.

Komunikasi dengan pemilik depot air minum tidak terjadi begitu saja karena hal itu harus direncanakan dan dibangun secara efektif. Siapa yang melakukan? Selaku penyelia layanan dan pengawasan sudah selayaknya Labkesda memunculkan inisiatif berupa rencana kerja membangun komunikasi dengan pelanggan. Komunikasi dibangun dengan cara mendekati langsung pemilik depot air minum. Labkesda juga mengusulkan agar pemilik depot air minum membentuk pagayuban pengusaha depot air minum agar saluran komunikasi antara Labkesda dengan pemilik depot air minum berjalan lancar, sayangnya usulan ini masih belum terealisasi sampai sekrang. Paguyuban atau himpunan pengusaha depot air minum dirasakan penting menginggat begitu luasnya wilayah Kabupaten Solok yang harus diawasi dimana tersebar ratusan depot air minum dimana ada puluhan depot yang tidak berizin,ada yang sudah tidak beroperasi lagi dan berbagai permasalahan lainnya sementara pegawai Labkesda hanyalah 9 orang. Komunikasi langsung ini penting untuk menyerap aspirasi pemilik depot air minum serta membantu permasalahan teknis pemilik depot air minum dalam mengawasi kualitas air minum. Pada umumnya tanggapan pemilik depot air minum baik saat petugas Labkesda melakukan penyuluhan tetapi tindak lanjut dari pemilik depot biasanya tidak ada.Mereka tetap enggan memeriksa kualitas air minum mereka secara rutin.

Komunikasi formal adalah proses komunikasi bersifat resmi yang biasanya dilakukan dalam lembaga formal melalui garis perintah yang berorientasi pada produktifitas.Berdasarkan struktur, organisasi berkomunikasi sebagai petugas organisasi dengan status masing-masing yang tujuannya menyampaikan pesan berkaitan kepentingan dinas. Pesan dalam komunikasi formal mengalir berdasarkan hierarki atau struktur resmi organisasi atau struktur resmi organisasi yaitu mengalir dari atas ke bawah, dari bawah ke atas ataupun antar anggota 
secara horizontal.Pesan tersebut berupa informasi yang berkaitan erat dengan organisasi seperti tugas,perintah,laporan,kebijakan dan sebagainya.Laporan Labkesda bisa dianggap komunikasi birokrasi secara horizontal dan diagonal dimana laporan diberikan kepada kepala seksi kesehatan lingkungan dan olahraga dimana secara struktural birokrasi dianggap horizontal.

Gambar 2 Jenjang dan Hambatan Komunikasi Birokrasi UPTD LABKESDA dalam pengawasan pemilik depot air minum

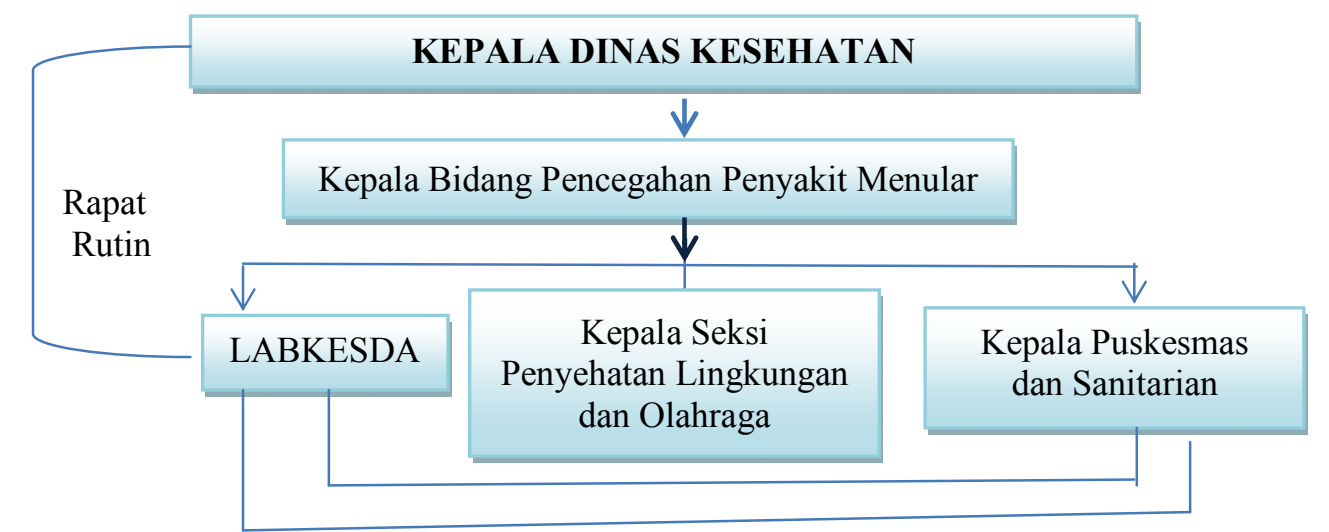

Koordinasi, Penghargaan dan Hukuman

Pemilik Depot Air Minum (Penghargaan dan Hukuman)

Laporan diberikan setiap bulan dimana laporan itu berisi data-data depot air minum yang memeriksa air minum tanpa memberikan hasil secara teknis.Hal ini karena itu adalah ranah rahasia antara Labkesda dan pemilik depot air minum.Jika ada pemeriksaan yang dinilai tidak memenuhi syarat maka sanitarian puskesmas yang dihubungi agar melakukan pembinaan ke pemilik depot air minum.Selama ini komunikasi sanitarian puskesmas terjalin baik karena ada kesepahaman dalam pengawasan kualitas air minum tetapi sanitarian tetap mengatakan tidak bisa memaksa pemilik depot air minum untuk memeriksa kualitas air minum secara berkala karena belum ada payung hukum daerah untuk memberikan sanksi administratif ke pemilik depot air minum. Komunikasi secara vertikal sering dilakukan secara lisan kepada kepala dinas keshatan dan kepala bidang pencegahan penyakit menular.Dalam rapat koordinasi bulanan,pimpinan Labkesda selalu menyampaikan agar semua pihak peduli terhadap pengawasan depot air minum.Pimpinan Labkesda juga menyampaikan agar adanya penghargaan dan hukuman bagi sanitarian yang tidak serius mengawasi depot air 
minm,sayangnya usulan ini mentah karena semua pihak terkesan mementingkan ego sehingga komunikasi terkesan terhambat dan ujungnya inovasi untuk pengawasan ini tidak muncul.

\section{Koordinasi antara Pemangku Kepentingan}

Pengawasan depot air minum ini adalah tanggung jawab bersama. Didalam pemerintah maka pihak-pihak yang terlibat antara lain Bagian perekonomian Sekretariat Daerah Dinas Kesehatan, Dinas penanaman modal, PTSP dan tenaga kerja, Dinas Koperindag, Dinas Satuan pamong praja dan pemadam kebakaran. Diluar pemerintah, pihak yang terlibat adalah pengusaha depot air minum, lembaga swadaya masyarakat serta masyarakat umum. Seharusnya semua pihak mampu membangun komunikasi yang baik sehingga terjadi kesepakatan untuk mengawasi kualitas air minum sehingga masyarakat terlindungi dari air minum yang tak layak konsumsi. Tim terpadu yang dikomandai oleh kepala daerah belum terbentuk sehingga pengawasan di lapangan terkesan lemah. Bupati sebagai atasan ASN di daerah memiliki kewewangan dalam menjalankan kebijakan. Bupati dapat mengunakan komunikasi vertikal sebagai pemberian instruksi kerja (job instruction) serta memberikan penjelasan dari pimpinan tentang mengapa suatu tugas perlu untuk dilaksanakan (job retionnale). Hambatan-hambatan komunikasi dapat diatasi dengan mudah jika kepala daerah mengunakan gaya manajemen top down sehingga jajaran dibawah akan bergerak sesuai prosedur yang berlaku. Komunikasi satu arah merupakan salah satu implementasi gaya kepemimpinan top down.

Koordinasi antar pemangku kepentingan akan berjalan efektif jika bupati turun langsung mengepalai tim pengawasan depot air minum. Pemberian teguran tertulis dan sanksi administratif untuk pemilik depot air minum yang bandel perlu dilaksanakan. Koperindag sebagai mitra utama pengusaha depot air minum seyogyanya mampu memotivasi pemilik depot air minum untuk menaati aturan yang berlaku.

\section{F. Kesimpulan}

Komunikasi birokrasi merupakan hal yang mutlak dalam menjalankan roda organisasi pemerintahan.Komunikasi birokrasi Labkesda dalam pengawasan depot 
air minum telah berjalan sebagai semestinya. Berbagai usulan dan ide yang diberikan kepada pimpinan diharapkan mampu meningkatkan kepatuhan pemilik depot air minum. Komunikasi langsung dengan pemilik depot air minum juga dilakukan untuk peningkatan partisipasi pemilik depot air minum. Komunikasi secara berkesinambungan juga dibangun dengan kepala seksi kesehatan lingkungan serta sanitarian yang berada di puskesmas. Pendanaan yang kurang bisa disiasati dengan memasukkan program pengawasan melalui dana Bantuan Operasional Kesehatan (BOK). Dalam menu BOK tersedia matriks untuk pembiayaan pengawasan kualitas air minum. Hukuman dan penghargaan adalah suatu keniscayaan agar masyarakat terlindungi dari potensi penyakit yang disebabkan oleh air tidak layak konsumsi. Pembuatan Standar Operasi Prosedur (SOP) pengawas depot air minum serta tim satuan tugas pengawasan depot air minum harus dibuat agar Surat Edaran Bupati tentang pengawasan depot air minum dapat diimplementasikan di lapangan.

Perencanaan, pengorganisasian, pelaksanaan, pengarahan serta pengawasan. Semua itu membutuhkan komunikasi efektif agar rantai organisasi yang bernama birokrasi dapat menjalankan roda pemerintahan sebagaimana semestinya. Komunikasi efektif serta berkesinambungan akan membuat pemilik depot air minum patuh terhadap ketentuan yang berlaku.

Komunikasi birokrasi perlu terus menerus dilaksanakan kepada semua pemangku kepentingan dalam bidang pengawasan depot air minum. Perlu ada usaha dan inovasi untuk meningkatkan kepedulian pemilik depot air minum serta masyarakat yang mengkonsumsi air minum isi ulang. Peraturan Daerah bisa dibuat dengan mengunakan salah satu bagian keputusan menteri Pekerjaan Umum tentang system penyaluran air minum.Pengembangan pendekatan pelaksanaan kebijakan pengawasan kualitas air minum dari ats ke bawah untuk pelaksanaan kebijakan.Secara teoritis pelaksanaan kebijakan meliputi tiga tahap keberhasilan dimana perencaan kebijakan mempunyai 20\% tingkat keberhasilan, eksekusi kebijakan memiliki 60\% tingkat keberhasilan serta 20\% ditentukan oleh pengendalian kebijakan. Pendekatan top down oleh kepala daerah bisa mengisi kekosongan saat perda pengawasan depot air minum belum terwujud karena sesungguhnya birokrasi memiliki wewenang mengatur masyarakat. Dinas 
kesehatan dan jajarannya bisa mengundang pengusaha depot air minum dalam pembinaan dengan melibatkan pihak kepolisian dan Wali Nagari sehingga ada komitmen yang terus terjaga dalam melindungi masyarakat dari bahaya kontaminasi air minum isi ulang yang tidak memenuhi persyaratan.

\section{Daftar Pustaka}

Albrow, Martin. 1998. Birokrasi. M.Rusli dan Totok Daryanto (pen).Yogyakarta: Tiara Wacana

Adiatama, R, Danang Endarto, Setya Nugraha. 2014. S tudi Persebaran Depot Air Minum Isi Ulang dan Kualitas Air Minum Isi Ulang Secara Mikrobiologis di Kecamatan Jebres Kota Surakarta Tahun 2014. Diakses dari http://download portalgaruda.org/article,php? article $=332584 \&$ val $=4079 \&$ title

Effendy, Onong Uchjana. 1999. Ilmu Komunikasi. Teori dan Praktek. Bandung: Remaja Rosda Karya.

Goldhaber, Gerald M. 1986. Organizational Communication Fourth Edition, Dubuque, IA:Wm. C.Brown Publishers.

Keputusan Menteri Perindustrian dan perdagangan RI Nomor 651/MPP/KEP/X/2009 tentang Persyaratan Teknis Depot Air Minum dan Perdagangannya.

Nurrohim, Hasan dan Lina Anatan. 2009. Efektivitas Komunikasi Dalam Organisasi. Jurnal Manajemen, Vol.7 No.4 Mei

Pradana, A.Y.,Bowo Joko Marsono. 2013. Uji Kualitas Air Minum Isi Ulang di Kecamatan Sukodono, Sidoarjo ditinjau dari perilaku dan pemeliharaan alat. Jurnal Teknis Pomits Vol.2,No.2,ISSN 23373539 (2301-9271 print)

Peraturan Menteri Kesehatan Nomor 492/MenKes/Per/IV/2010 tentang Persyaratan kualitas air minum.

Peraturan Menteri Kesehatan Nomor 411/MenKes/Per/III/2010 tentang Laboratorium Klinik;

Robbins, Stephen P\&Coulter, Mary. 2010. Manajemen Edisi Kesepuluh. Jakarta:Erlangga

Thoha, Miftah. 2008. Birokrasi Pemerintahan Indonesia di Era Reformasi. Jakarta: Kencana Prenada Media Group.

Wandrivel, R, Netti Suharti, Yuniar Lestari. 2015. Kualitas Air Minum Yang Diproduksi Depot Air Minum Isi Ulang di Kecamatan Bungus Padang berdasarkan Persyaratan Mikrobiologi. Diakses dari http://jurnal.fk.unand.ac.id/articles/vol_1 no 3/129-133.pdf (Mei. 2015) 